\title{
Creativity of Virtual Dance Competition of "Beksan Nir Corona" in The Kraton of Yogyakarta
}

\author{
Kuswarsantyo Kuswarsantyo ${ }^{\bowtie}$, Otok Fitrianto
}

\author{
Universitas Negeri Yogyakarta, Indonesia
}

Submitted: June 24, 2020. Revised: September 9, 2020. Accepted: November 18, 2020

\begin{abstract}
The objectives of this study are to: (1) describe and analyze the arrangement tutorial of Beksan Nir Corona on a virtual dance competition in the Kraton of Yogyakarta; and (2) describe and analyze the level of similarity in imitation of movement patterns and creativity in the presentation of the participants in the dance competition of Beksan Nir Corona. The method used in this research is descriptive qualitative supported by percentage descriptive quantitative data. The data collection process was carried out using observation, interview, and document techniques. Data analysis was carried out by the stages of data reduction, data presentation, and drawing conclusions. The research results show that the virtual dance tutorial of Beksan Nir Corona as a competition guide contains a recording of a dance model, which is a stylization of five steps of washing hands into a simple variety of movements in the classical dance of Yogyakarta style. Judges' assessment results through dance performance videos uploaded by 196 participants showed that: (1) the ability of participants to imitate all movement patterns according to the dance material of Beksan Nir Corona reached $85 \%$; (2) the ability of participants to be creative which is manifested in the ability to express ideas only reached $60 \%$; and (3) the remaining $40 \%$ of participants only danced the dance of Beksan Nir Corona by imitating the movement patterns that had been exemplified. The average ability to imitate the movement patterns of the dance of Beksan Nir Corona based on the assessment of the six judges is 85.5. In contrast, the creative ability in dance presentation is 70.5.
\end{abstract}

Keywords: creativity; Beksan Nir Corona; virtual dance competition

How to Cite: Kuswarsantyo, K., \& Fitrianto, O. (2020). Creativity of Virtual Dance Competition of "Beksan Nir Corona" in The Kraton of Yogyakarta. Harmonia: Journal of Arts Research And Education, 20(2), 135-143

\section{INTRODUCTION}

Since March 16, 2020, the Indonesian government officially stated that the Covid-19 Pandemic had begun to enter Indonesia. Therefore, since then,, the Indonesian government has imposed a Work from Home (WFH) policy, which must be implemented by all parties. Various activities, both in offices, schools, and various other activities, including the arts, must not be done face-to-face. Responding to this situ- ation, the Kraton of Yogyakarta responded positively so that artistic activities would not stop during the Covid-19 pandemic. One of them was done by bringing up the idea of holding a virtual dance competition with the headline \#menaridirumahaja.

In organizing the dance competition, Beksan Nir Corona is created and selected as the material object. Nir means nothing, and Corona is Covid-19, which is currently outbreaking. The dance of Nir Corona is made as to the title of a dance with the expecta-

\footnotetext{
${ }^{\square}$ Corresponding author:

E-mail: kuswarsantyo@uny.ac.id
} 
tion that the corona victims do not grow again and soon gone. The idea for this dance came from KPH Notonegoro, pengageng Kawedanan Hageng Poenokawan (KHP) Kridha Mardawa Kraton Yogyakarta, assisted by Abdi Dalem mataya (dancer) RJ. Pulung Ronggomataya (Raden Jajar) and MJ. Animayong Sarimataya, as well as other dancers (mataya) as demonstrations.

The contents of the dance of Beksan Nir Corona describe the handwashing procedures that must be applied during the Covid-19 outbreak. The WHO's handwashing procedure (World Health Organization) became a reference for various movements, then it was transformed into a simple arrangement of classical dance in Yogyakarta style. The five steps for washing hands which are the ideas in this dance include (1) washing between palms; (2) washing the joints in the finger joints; (3) washing the tips of the fingers by squeezing them; (4) tightening the thumbs by rotating it; and (5) tightening and rotating the palms completely. The arrangement of Beksan Nir Corona is made as a medium to socialize healthy living habits by washing hands and using hand sanitizers.

The implementation of the virtual dance competition in the Kraton of Yogyakarta in the context of education can be used as a model in implementing distance learning. This can be observed, starting from the initial procedure for the process of pouring out ideas to uploading tutorial material, which is a combined pattern to realize an effective learning process. This process is in accordance with a learning model that combines aspects of etymology, social, psychological, and pedagogical approaches that connect the brain and body, between individuals and individuals, between individuals and communities, and between domains of knowledge. In other words, it is a blended model of learning development that seeks to combine several subjects (Beane, 1995)

The imitative learning model in dance is currently the simplest to do. However, with the Synthesis Analysis structural model's combination, the learning model will be effective, as has been applied in the virtual dance competition in the Kraton of Yogyakarta. Thus, it is clear that the implication of the idea of a virtual dance competition can be applied as a practical learning model with other dance materials according to each institution's needs.

Kraus (1977) states that learning of movement education in physical education is an integrated lesson that can contribute to the development of effective, efficient, and expressive movement responses in students to express thoughts and feelings to others. Relevant to this statement, the exploration method in this context will be the main method centered on students (competitors) as individuals who are able to discover themselves (self-discovery) spontaneously. Therefore, this phenomenon shows how important competition tutorials' role is in motivating and driving the dance creativity in participants or students when applied in learning (Jazuli, 2008).

In line with Jazuli's opinion above, the concept of learning carried out by Kridha Mardawa with Beksan Nir Corona in the virtual dance competition has implemented the idea of cultural integration into technology. This is expressed by Kusumastuti (2004: 1) that the use of virtual media as the implementation of new concepts in learning is an integrated approach that can provide a holistic understanding for competition participants or students (Kusumastuti, 2004). Based on this background, the objectives of this study are to (1) identify and analyze the arrangement of Beksan Nir Corona in the virtual dance competition in the Kraton of Yogyakarta; (2) know and analyze the level of similarity in the imitation results of the competition material of Beksan Nir Corona in the Kraton of Yogyakarta.

\section{METHOD}

This research is a qualitative descriptive study based on the observation of the process, starting from the making of learning materials of virtual dance, the upload 
process, and the implementation of the assessment. Observation, interviews, and documents carried out data collection techniques. Observation activities were carried out during the process of making virtual dance competition materials and during the competition. Interview activities were carried out with the speakers during the process and after the dance competition. Resource persons in interview activities include (1) KPH. Notonegoro as the initiator of the competition; (2) MJ. Ronggomataya and Animayong Sarimataya as dance stylists; and (3) MJ. Murpratomo Kumudamataya is the coordinator of the judging team. The research documents as a source of data in this study are competition tutorials, recordings of competition results, and judgments from the judges. To ensure the data's validity, a source triangulation was also carried out, namely 20 participants in a dance competition that were determined purposively. Data analysis was carried out by the stages of data reduction, data presentation, and drawing conclusions. Data analysis activities are needed in the process of arranging data sequences and organizing them into patterns, categories, and basic description units (Brannen, 1997).

\section{RESULTS AND DISCUSSION}

\section{The arrangement tutorial of Beksan Nir Corona for Virtual Dance Competition}

Dance competitions are generally conducted face-to-face. However, under conditions of limitation due to the Covid-19 pandemic, dance competitions virtually are the most likely alternative solution. This is because we can still maintain social distancing and physical distancing as recommended by the government.

In the world of entertainment, the term 'virtual' is often used to publish other products or services. But for the level of traditional arts, especially classical dance in Yogyakarta style, this virtual dance competition is something new. The classical dance, which is usually contested, requires space and time as well as the readiness of the organizers in a certain location, but with this condition, there is no need to prepare the venue and the equipment for the competition. The participants only need to study the material from home, record dance movements from home, upload the recordings, and wait for the judges' assessment results.

Another dimension of the preparation for this Virtual Dance Competition is that each participant can record repeated movements. The best one can be selected according to the tutorial carried out by the organizing committee before uploading. In addition, the freedom to add and or develop the concept of presentation is an opportunity for participants to express their creativity.

This virtual competition model organized by Kraton Yogyakarta not only presents the concept of practicality in its implementation but more importantly in the process. This virtual competition creates a psychological effect which according to Gardner is not for personal gain, but for the collective interest of everyone. can feel the results of personal creativity.

At least Gardner (1983) reveals that there are seven aspects that arise related to independent learning, namely; (1) linguistic intelligence; (2) musical intelligence; (3) mathematical logical intelligence; (4) spatial intelligence; (5) kinesthetic intelligence; (6) interpersonal intelligence; (7) intrapersonal intelligence.

The tutorial used in virtual dance competitions as a guide for participants contains an overview of the various movements that must be developed. The movement illustration that must be developed comes from the five steps of washing hands, as summarized in the Figure 1.

Based on the five steps of washing hands, a dance tutorial is made that is displayed as simple as possible, making it easier for participants to learn and follow it. As a learning model, the competition committee's tutorials are intended so that the aesthetic learning process can take place systematically. The feedback from the learning model has a positive effect on the participants' learning process (Kusu- 
mawardani, 2019). An illustration of the tutorial movements of the dance competition of Beksan Nir Corona in the Kraton of Yogyakarta can be seen in Figures 2 and 3.

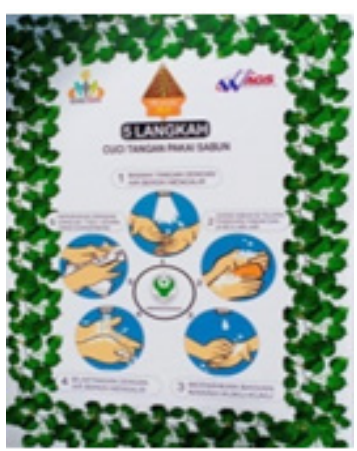

Figure 1. The five steps of washing hands that inspire the movement of Beksan Nir Corona

(doc. Din. Kes. Yogyakarta City, 2020)

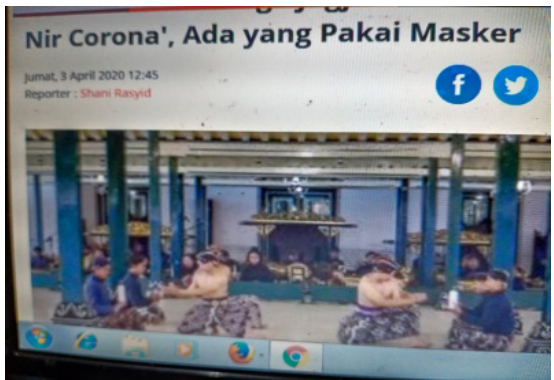

Figure 2. Beksan Nir Corona in introduction part (Source: Tandhayekti of the Kraton of Yogyakarta, 2020)

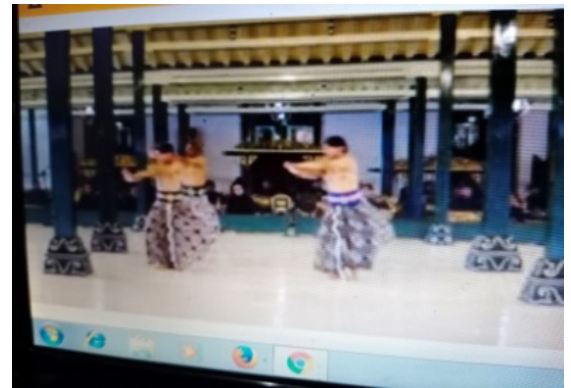

Figure 3. The movement variation of keplok asta (Source: Tandhayekti of the Kraton of Yogyakarta, 2020)

The step of the tutorial arrangement of Beksan Nir Corona in this virtual dance competition is carried out in the following stages: (1) exploring handwashing procedures in the Covid-19 era; (2) improvising movements based on classical dance in Yogyakarta style; (3) performing movement stylization, from pure movement to symbolic movement; and (4) compiling a series of Beksan Nir Corona complete with movement transitions based on the criteria of the dance movements in Yogyakarta style. After the formation of Beksan Nir Corona, the KHP Kridha Mardawa team conducted an internal discussion to see how the difficulty level resulted from the arrangement of Beksan Nir Corona.

MJ Ronggomataya, abdi dalem mataya who composed the movements of Beksan Nir Corona stated that the arrangement of the various movements was deliberately created as simple as possible. The aim is to facilitate the adaptation and imitation of participants. This was confirmed by KPH. Notonegoro, as the person in charge of the activity that the educational and entertaining aspects of working from home are the main objectives. Education in terms of understanding traditional culture (cognitive) and dance practice (psychomotor). The arrangement of the movements of Beksan Nir Corona is described in detail in Table 1.

The tutorial for the dance of Beksan Nir Corona was delivered to the public through YouTube. Initially, the use of technology in traditional arts was responded with pessimism and even considered unnecessary. However, over time, it seems that traditional art and technology cannot be separated. As a result, what the public does not know at large, now people can easily understand how the position, history, function, and technical presentation of art around the world, only by opening access through technological devices from their own houses.

The use of technology in the dance learning system is now a necessity. Its implementation can help facilitate the transfer of knowledge and skills for students. As a distance learning model, this process answers doubts that learning dance material does not have to be face to face. It was proven based on the judge team's assessment results showing that $85 \%$ of participants were able to transfer their visual observations to the dance of Beksan Nir Corona. Only $15 \%$ of participants could not still observe the existing dance move- 
Table 1. The arrangement of movements of Beksan Nir Corona in the virtual dance competition in the Kraton of Yogyakarta

\begin{tabular}{lcc}
\hline Variety of movements & Quantification & Floor pattern \\
\hline $\begin{array}{l}\text { Sembahan sila (greet and bow), tangkep asta (clap hands) right } \\
\text { and left }\end{array}$ & $4 \times 8$ & 0 \\
Jengkeng (bow), wash hands realistically with hand sanitizer & $4 \times 8$ & Static four-four \\
Stand, Sabetan & $1 \times 8$ & Static four-four \\
Drop tangkep asta wash hands, right & $2 \times 8$ & Static four-four \\
Drop tangkep asta wash hands, left & $2 \times 8$ & Static four-four \\
Sendi sabetan & $1 \times 8$ & Static four-four \\
Clap hands ingset, right and left & $2 \times 8$ & Static four-four \\
Nglawe, hold the right-left thumbs consecutively & $4 \times 8$ & Static four-four \\
Sendi Sabetan & $1 \times 8$ & Static four-four \\
Hold the palms of hands, rub, right-left & $2 \times 8$ & Static four-four \\
Sabetan Tancep, finish & $1 \times 8$ & Static four-four \\
\hline
\end{tabular}

ment patterns so that the accuracy in imitating the movement patterns was still not appropriate. Based on these results, it can be said that the tutorial developed by the virtual dance competition organizer in the Kraton of Yogyakarta has been effective.

The creativity of Participants in the Virtual Dance Competition of Nir Corona in the Kraton of Yogyakarta

The virtual dance competition of Beksan Nir Corona in the Kraton of Yogyakarta on April 2, 2020, was attended by 196 participants. In a relatively short time for approximately 12 days, the participants must do two things, namely imitating and creating a dance form based on the competition guide and existing video tutorials. To do these two things, of course, the participants are required to focus on the various types of movements that are in the dance of Beksan Nir Corona. The process of creation of the participants, according to Hawkins (1991), can be done in stages: (1) Sensing (feeling); (2) Feeling (feeling in participating in a competition); (3) Imaging; (4) Transforming; (5) Forming. Therefore, based on the existing tutorial, the participants have experienced directly how dance is learned and felt, thus forming an interesting presentation that reflects their creativity. One of the appearances of the virtual dance competition of Beksan Nir Co- rona can be seen in Figure 4.

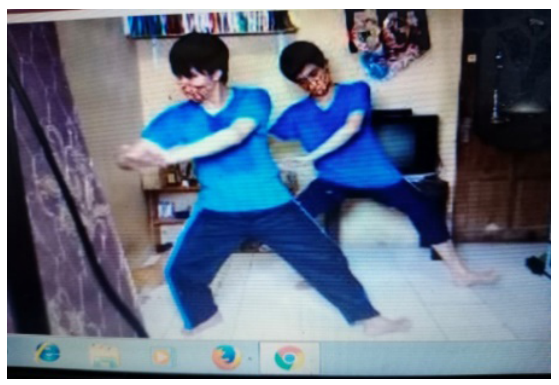

Figure 4. One of the participants of the virtual dance competition (Source: screenshoot, tandhayekti the Kraton of Yogyakarta, 2020)

Responses to the virtual dance competition material from the participants in this study were classified into two aspects. The first aspect is related to the level of material difficulty (imitation), and the second aspect is related to presentation arrangement opportunities (presentation creativity). The participants' responses to the aspect of the difficulty level of the material show that, in general, the material is not too difficult to learn and imitate. Meanwhile, from the opportunity for the arrangement of dance presentations, the participants stated that they still have very creative opportunities to create various dance movements based on existing tutorials. The positive response from the participants of the virtual dance competition of Beksan Nir Corona was as expressed by 
Jerry as follows.

.... The online dance competition is exciting and a new challenge. The material in this competition is easy to do, and opportunities to create are open; hopefully, there will be such competition next year.

A similar opinion was also expressed by Khoria Fadillah, one of the female participants who stated.

..... The opportunity to express with the dance of Beksan Nir Corona is very challenging, and we have no trouble doing it. This competition attracts all of us.

Regarding the assessment criteria which require participants to be able to make creative arrangement in addition to imitation, Ferry Komper argues as follows. ..... This is really a challenge for the participants. But in my opinion, it doesn't matter because the theme of this dance is relevant to the situation that occurred in the Covid-19 Pandemic, so we can easily do it according to the situation around us.....

Beksan Nir Corona, which was used as material for the Virtual Dance Competition, according to the participants' opinion, was not difficult. Two important aspects of this dance competition, namely the ability of participants to imitate the existing movement patterns and the ability to create based on new ideas in the dance of Beksan Nir Corona are possible. This is in accordance with the expectations of the initiators and organizers of the dance competition of Beksan Nir Corona.

Participants' interest in this dance competition can be taken into consideration for organizing similar dance competitions in the future. According to Gardner (1983), the imitation produced by participants in participating in this virtual dance competition is determined by (1) musical intelligence, (2) kinesthetic intelligence, and (3) interpersonal intelligence.

Musical intelligence is related to the auditive stimuli that participants must have to help express movements according to the music's tempo or rhythm. The kinesthetic body's intelligence is related to dancers' flexibility in performing movements of Beksan Nir Corona. The interpersonal intelligence is related to dancers' personal responsibility in actualizing Beksan Nir Corona in groups to participate in virtual dance competitions.

Regarding the interaction in the process of participating in the virtual dance competition, Lotman (1977) states views art as a specific way of communication, as a "language" that is structured in a "strange" way. The word "strange" here should be understood as something "unusual." He gave the term "language" (code) as a comprehensive meaning, which is generally referred to in semiotics as a regulated system, which acts as a means of communication and uses signs. Art is similar to a well-organized language generator. This means that there is indeed a "language of art," in addition to the relationship between language and certain artistic texts (Sayuti, 2012).

The results of judges' assessment through dance performance videos uploaded by 196 participants showed that: (1) the ability of the participants to imitate all the movement patterns in the dance material of Beksan Nir Corona reached 85\%; (2) the ability of participants to be creative which is manifested in the ability to express new ideas as expected only got $60 \%$; and (3) the remaining $40 \%$ of participants only danced the dance of Beksan Nir Corona by imitating the movement patterns that had been exemplified.

The average of mimicking abilities (imitating) of dance movement patterns of Beksan Nir Corona based on an assessment of 6 judges from 196 participants is 85.5. At the same time, the creative ability in dance presentation is 70.5. Hence, the concept of the virtual dance competition of Beksan Nir Corona from the Kraton of Yogyakarta has proven its effectiveness when viewed from an interactive approach based on visual imitation sensitivity. In practical learning theory, it is stated that imitation is the main basis for accelerating the process of understanding the material being taught 
(Kusnadi, 2018)

The level of similarity (accuracy) in imitating movement patterns of Beksan Nir Corona and the creativity of the participants in its presentation varies greatly. Based on the data from the assessment results of the 20 participants who were nominated for the virtual dance competition of Beksan Nir Corona in the Kraton of Yogyakarta, it can be explained as Table 2 .

Assessment of participants' competence in the aspect of the ability to imitate movement patterns and creativity in the presentation of the dance of Beksan Nir Corona by judges was carried out with a score range between $60-95$ by using multiples of 5 (five). The score for the level of imitation and creativity is done with the following indicators (Table 3).

Based on the data, Table 2 shows that the imitation abilities and creativity of the 20 participants who entered as the winner nominees are: (1) the creativity scores of 3 participants are higher than the imitation ability score; (2) 9 participants have the same creativity score as the imitation ability score; and (3) the creativity scores of 8 participants are lower than their imitation ability scores. This shows that dancing skills are only one component of dance creativity. The rest is necessary to have the ability to come up with new ideas to develop and create a variety of dance movements following the set competition theme. Guilford (1973) explained that in the art of dance, creativity requires other matters concerning fluency, flexibility, redefinition, and elaboration that enable the emergence of original ideas in the process of dance creation. Relevant to the theory of creativity, dance creativity also needs other things concerning fluency, flexibility, redefinition, and elaboration that allow the emergence of original ideas in the process of dance creation (Guilford, 1973).

Table 2. The level of similarity of movement patterns and creative abilities of the participants in the virtual dance competition

\begin{tabular}{ccc}
\hline Name & \multicolumn{2}{c}{ Score } \\
\cline { 2 - 3 } & Movement Imitation & Presentation Creativity \\
\hline Dwi Prasetyo & 85 & 85 \\
Angga Uka- uka & 85 & 85 \\
Jerry & 90 & 85 \\
Ferry Komper & 90 & 85 \\
Friday & 85 & 90 \\
Suwarjiyo & 85 & 85 \\
Dillo & 85 & 90 \\
Yudha Wicaksono & 85 & 85 \\
Kidung & 85 & 85 \\
Rangga & 85 & 85 \\
Anggoro & 85 & 80 \\
Amrih Gunarto & 85 & 80 \\
Fadil & 80 & 85 \\
Irim irim Laraswangi & 90 & 85 \\
Muharam B. M. & 90 & 85 \\
Risang & 85 & 80 \\
Khoiria Fadilla & 90 & 90 \\
Ratih Dwi Anjani & 85 & 80 \\
Sheryl Intan & 80 & 80 \\
Pramono & 80 & 80 \\
\hline
\end{tabular}


Table 3. Scores and indicators of the level of similarity of movement patterns and creative abilities of participants in the virtual dance competition of Beksan Nir Corona in the Kraton of Yogyakarta

\begin{tabular}{|c|c|c|}
\hline \multirow[t]{2}{*}{ Score } & \multicolumn{2}{|l|}{ Indicator } \\
\hline & Level of imitation & Presentation creativity \\
\hline $60-65$ & $\begin{array}{l}\text { Not able to imitate all parts of the movement } \\
\text { pattern according to the model }\end{array}$ & $\begin{array}{l}\text { Not able to display creativity in all } \\
\text { parts of the dance performance }\end{array}$ \\
\hline $70-75$ & $\begin{array}{l}\text { Only imitate some movement patterns according } \\
\text { to the model }\end{array}$ & $\begin{array}{l}\text { Able to show creativity in a small } \\
\text { part of the dance performance }\end{array}$ \\
\hline $80-85$ & $\begin{array}{l}\text { Able to imitate all movement patterns but cannot } \\
\text { express it according to the model }\end{array}$ & $\begin{array}{l}\text { Able to show creativity in half } \\
\text { parts of the dance performance }\end{array}$ \\
\hline $90-95$ & $\begin{array}{l}\text { Able to imitate all part of the movement pat- } \\
\text { tern and being able to express it according to the } \\
\text { model optimally }\end{array}$ & $\begin{array}{l}\text { Be able to display creativity in all } \\
\text { parts of the dance presentation }\end{array}$ \\
\hline
\end{tabular}

\section{CONCLUSION}

The virtual dance competition of Beksan Nir Corona organized by the Kraton of Yogyakarta, which was attended by 196 participants, received positive responses from the community. The guide and tutorial of virtual dance competition of Beksan Nir Corona, which contains a recording of a stylized dance model of five steps of washing hands into a simple variety of movements of classical dance in Yogyakarta style, can guide participants in practicing existing dance movement patterns and are able to stimulate participants to be creative.

The ability of competition participants to imitate all movement patterns according to the dance material of Beksan Nir Corona reached $85 \%$. Meanwhile, participants' ability to be creative in the form of the ability to express ideas only got $60 \%$. The difference in dance competition participants' ability to imitate and be creative is due to participants' ability to practice various dance movements; only one important component in dance creation. Apart from the ability to dance properly, other things are needed relating to the ability to create, namely fluency, flexibility, definition, elaboration, and original ideas of dance creation.

\section{REFERENCES}

Aminatun, T. (2020). Belajar Dari Covid 19. Yogyakarta: UNY.

Gardner, H. (1983). Frames of Mind. New York: Liberty, ltd.

Guilford, J. P. (1973). A Psychometric Approach to Creativity. In Bloomberg, M. (Ed.), Creativity: Theory and Research (pp. 229-246). New Haven, Conn: United Printing Service, Inc.

Hawkins, A. M. (1991). Bergerak Menurut Kata Hati. ed. Wayan Dibia. Jakarta: Ford Foundation dan MSPI.

Jazuli, M. (2008). Paradigma Kontekstual Pendidikan Seni. Surabaya: Unesa University Press.

Kraus, R. (1977). History of the Dance. New Jersey: Prentice, Inc.

Kusnadi. (2008). Strategi Pembelajaran Praktik. Yogyakarta: UNY.

Kusumastuti, E. (2004). Pendidikan Seni Tari Pada Anak Usia Dini Sebagai Proses Alih Budaya. Harmonia: Journal of Arts Research and Education 5(1).

Kusumawardani, D. (2019). Aesthetic Learning by Implementing Systemic Approach to Achieve Educational Values in Performing Arts. Harmonia: Journal of Arts Research and Education 19(2),126-132.

Nickelsen, E. \& Lee Ann. (2011). Deeper 
Learning (the Seven Strategy for Learning). Ed. PT Indeks. Jakarta.

Nicolisch, W. (2010). Motoric, Skills, and Learning. Imaji: Jurnal Seni dan Pendidikan Seni.

Notonegoro, K. P. H. (2020). Lomba Tari Nir Corona. Yogyakarta: Kraton Yogyakarta,Tepas Tandhayekti.

Sayuti, S. A. (2012). Pengkajian Jagat Seni Sebagai Sistem Penandaan, Dalam Buku
Greged Joged Jogja. Yogyakarta: Bale seni , SMKI, ISI and UNY.

Soenartomo. (1998). Struktur Analisa Sintesa Dalam Pembelajaran Tari. Yogyakarta: SMKI.

Walton, J. (1999). The Art and Science of Teaching Learning Dance. http:// www.joanwalton.com/Home/Essays/the-art-and-science-of-teachinglearning-dance. 